This PDF is a selection from a published volume from the National Bureau of Economic Research

Volume Title: Health and Labor Force Participation over the Life Cycle: Evidence from the Past

Volume Author/Editor: Dora L. Costa, editor

Volume Publisher: University of Chicago Press

Volume ISBN: 0-226-11618-2

Volume URL: http://www.nber.org/books/cost03-1

Conference Date: February 2-3, 2001

Publication Date: January 2003

Title: Pensions and Labor Force Participation of Civil War Veterans

Author: Tayatat Kanjanapipatkul

URL: http://www.nber.org/chapters/c9634 


\section{Pensions and Labor Force Participation of Civil War Veterans}

Tayatat Kanjanapipatkul

\subsection{Retirement and Civil War Pension System}

During the last century, retirement became an increasingly important aspect of the U.S. labor market. The retirement rate increased substantially, and more Americans began leaving the labor market at earlier ages, changing the ratio of retirees and workers. These changes coincided with the advent of the Social Security system and old age and disability benefits programs, which have grown significantly. The extent to which these benefits affect retirement not only is an interesting issue to analyze, but is also an important question to ask from the point of view of public policy. The desirability of these programs must be viewed in light of the reduction in the labor force they produced.

Several studies have attempted to empirically measure the change in labor force participation produced by nonlabor income from various programs. This paper will approach the issue by using Civil War pension data to identify the effect of pension income on the labor force participation of veterans. The original researcher in this area is Costa (1993, 1995b, and 1998a), who finds that a substantially lower participation rate of the Union Army veterans compared to the U.S. population at large resulted from the income effect of the federal pension system. In addition, comparisons over time reveal a declining elasticity of retirement with respect to income. Recently, the Center for Population Economics (CPE) at the University of Chicago and the Integrated Public Use Microdata Series (IPUMS) project

Tayatat Kanjanapipatkul received his Ph.D. in economics from the University of Chicago. Valuable comments from Dora Costa, Robert Fogel, James Heckman, Peter Viechnicki, Todd Bridges, volume referees, participants at the NBER conference, and the Center for Population Economics are gratefully acknowledged. 
at the University of Minnesota released new data sets that are suitable for this analysis. The availability of these new, larger, and more comprehensive data makes it sufficiently important to reexamine the earlier estimates of the impact of the Civil War pension on retirement rate among the Union veterans. This paper will also explore several ways to model the Civil War pension. Instead of using only the average monthly pension income, several measures of pension income such as the total lifetime amount and the inflation-adjusted amount will be employed in the regressions. In addition, this paper will try to identify the treatment effect of pensions by making a comparison between the Union and the Confederate veterans.

The Civil War pension program granted a large pension income to Union veterans. Over the decades that followed the war, there was a large expansion of the program both in its magnitude and scope. By the end of the nineteenth century, veterans were no longer required to prove that their disability was related to the military service in order to be eligible for a pension. Old age became the minimal eligibility requirement in the early years of the twentieth century. By 1910, more than 90 percent of Union Army veterans were receiving federal pensions. The average pension was $\$ 189.08$ a year. This amount represents 74 percent of a farm laborer's average annual income, 51 percent of a laborer's average annual income, and 22 percent of a professional's average annual income. ${ }^{1}$ The Report of the Commissioner of Pensions for 1917 stated that the total amount paid to the pensioners of the Civil War was over $\$ 4.9$ billion, which is 70 times larger than the amount paid to pensioners of the War of the Revolution, 86 times larger than the War with Spain, 96 times larger than the Mexican War, and 107 times larger than the War of 1812.

Figure 9.1 plots the mean pension income per veteran. ${ }^{2}$ To account for inflation, both the nominal value and the real value are plotted. The real value was computed by compounding or discounting the nominal value by an interest factor. ${ }^{3}$ The base year in the computation is 1910 . The interest factor for any year is the product of annual interest rate between that year and 1910. In contrast to the nominal pension profile, the real profile is relatively

1. The average annual income of farm laborers, laborers, and professionals are imputed annual incomes in 1900 calculated by Preston and Haines (1991).

2. The CPE data set records the amount of pension received for each pension application. For each application, the total pension amount is converted into the annual pension income. Then the pension profile is constructed by combining amounts in the same year from all applications together. Missing values in the ending date of the pension ruling are replaced by the beginning date of the next pension ruling. The fluctuation in the right tail of the plot occurs because of the small sample size.

3. The nominal interest rate used for the computation is the yield of the American railroads bond. The yield stops being published in 1937. After 1937, corporate bonds' yield (Moody's Aaa) is used. These numbers are obtained from Series X 476-477 in the U.S. Bureau of Census (1975). The computation of the real profile is as follows. Denote nominal pension income by $A_{t}$, and real interest rate by $r_{t}$. For any period $t$ after 1910 , the real value is $A_{t} /\left[\Pi_{i=1910}^{t}(1+\right.$ $\left.r_{i}\right)$ ]. For any period $t$ before 1910, the value is $A_{t} \Pi_{i=t}^{1910}\left(1+r_{i}\right)$. 


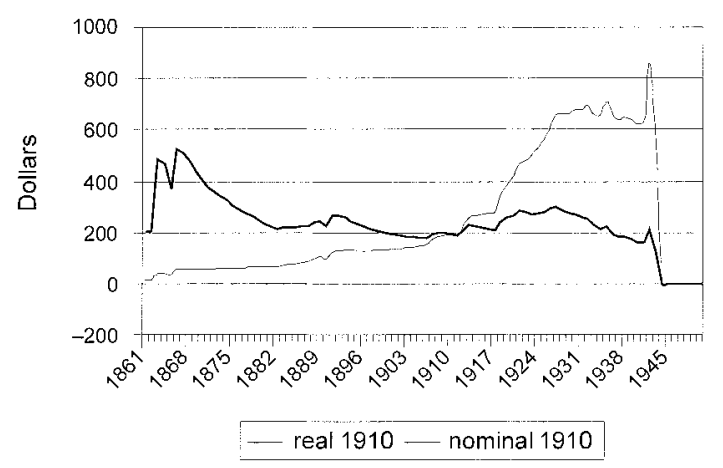

Fig. 9.1 Average annual pension income

flat, and is bounded within the range of $\$ 150$ to $\$ 300$ per year except for the years immediately following the war. Humps observed in the left tail of the discounted real profile are expected because the left tail is composed of veterans who received pensions immediately after the war at young ages. Most of these veterans could attribute their disabilities to the war, which allowed them to claim large pension incomes. After the revision of the pension law in 1890 , veterans were not required to trace their health problems to the war. Hence, the pensioners after 1890 were composed more of veterans who developed health problems unrelated to their military service. The pension law provided a smaller amount of pension income to them.

Unlike most social insurance schemes, the federal pension was not a compensation for a loss of job, nor were the veterans required to stop working to be eligible for the pension. It did not produce a labor-leisure substitution effect. In general, the amount of the pension was granted based on rank, age, health conditions, the severity of disability (if any), and whether the disability was related to military service. The magnitudes of income and eligibility depend on which pension systems the veterans applied under. The Civil War pensions can be divided into two systems, the disability pension and the service pension system. The disability pension system, also known as the invalid pensions system and the General Law system, was created during the war. Its establishment was intended to attract voluntary enlistment by providing compensation to veterans who were injured during the war. Pensions were granted based on rank and the severity of the injury or disease contracted. According to Glasson,

In passing the act of 1862 , Congress founded what has been called in the Bureau of Pensions the "general law pension system." This was the only system of pension laws in force and applying to the Civil War until 1890. It provides pensions for soldiers who have incurred permanent bodily injury or disability in military service after March 4, 1861. The claimant must show that his disability was incurred as the direct consequence of 
the performance of his military duty ... from causes which can be directly traced to injuries received or disease contracted while in military service. ... For disabilities caused by wounds received or disease contracted while in the service of the United States and in the line of duty, the act of 1862 granted pensions graded according to rank from thirty dollars to eight dollars per month in cases of total disability. . . . Proportionate pensions were to be given in each rank for partial disability. . . . In all cases invalid-pensions were to continue during the existence of the disability $(1918,125-26)$.

In contrast, the service pension system was created in 1890, and was intended to provide pensions to veterans who served the Union Army, whether or not they were injured during their service: "The Service Pension System provides pensions based on proof of the fact of military service in the Civil War for a period of ninety days or more and honorable discharge, coupled with the existence of a bodily disability not shown to be of service origin, or with the attainment of a certain age" (Glasson 1918, 125-26).

At the beginning of the service pension system, veterans were granted pension based on their health conditions alone. Old age was not pensionable until 1904 when the Roosevelt administration issued an executive order that allowed old age to be considered a health condition. The order became a part of the pension law in 1907:

[Order no. 78] provided that in the adjudication of claims under the act of 1890, as amended, "it shall be taken and considered as an evidential fact, ... that, when a claimant has passed the age of sixty-two years he is disabled one-half in ability to perform manual labor and is entitled to be rated at six dollars a month; after sixty-five years at eight dollars a month; after sixty-eight years at ten dollars a month and after seventy years at twelve dollars a month. (Glasson 1918, 247)

The service pension system was a controversial plan. Many critics asserted that the plan was extraordinary liberal, and was made possible through the influence of the Union veterans in politics. On this issue, Glasson wrote,

The Disability Pension Act of 1890 . . was really a service-pension law subject to a limitation - the existence in applicants of disabilities, regardless of origin ... pensions were granted to ex-soldiers for incapacity to perform manual labor in such a degree as to render them unable to earn a support. ... But a man might be in receipt of a comfortable of handsome income from his services as a skilled worker, salesman, clerk, lawyer, physician, public official, business man, or banker without thereby being ineligible for a pension. The law inquired only as to the ability of the applicant to perform crude manual labor, and rated in an arbitrary manner those physical and mental ills which, when of a permanent character, would hamper a man in performing such labor... 
Wealth, income, salary, ability to make a good living were ignored. (Glasson 1918, 236-37)

Union veterans could apply for pensions under both systems, the General Law system and the 1890 system. If both applications were approved, the veterans had to choose to receive their pension from only one system. This feature did not lead to a selection problem among the eligible. Many veterans switched from the disability pension system to the service pension system because, under the second system, the disabilities caused by the war as well as those unrelated to the war were pensionable. Only veterans with severe disabilities due to the military service, such as loss of sight, arms, or legs, chose to remain in the first system. For these types of veterans, the question about pension income and their labor force participation is not the main focus of this study. The analysis that follows will examine the pensioners under the service pension system and the selection problems that arise from the eligibility requirements of the pension law.

This paper is organized as follows. Section 9.2 discusses the estimation of the treatment effect by comparing the participation rates of Confederate and Union veterans. Section 9.3 attempts to identify the effect of pensions by using the variation in pension income among Union veterans to predict their participation status. Section 9.4 provides concluding remarks.

\subsection{Eligibility Requirements, Selection, and Estimation of the Treatment Effect}

The parameter of interest in evaluating the effect of pensions on labor force participation is the effect of the treatment on the treated, which reflects the reduction in the probability that a Union veteran would work compared to the probability he would have worked without receiving pension. The estimation of this parameter is complicated by the fact that there are no labor market data on the extent to which Union veterans would have worked if they were not granted the pensions, since most of them received the federal pension. Despite this problem, one way to estimate this parameter is to approximate the participation rate of the Union veterans not receiving pension by using the labor force participation of a control group whose characteristics are similar to those of the Union veterans, but who did not receive pension. Although it is possible to use the Northern population who did not fight in the war as a control group, the effect of war makes it unlikely that their physical health is comparable to that of the veterans. As a result, the following analysis will use the Confederate veterans as a control group.

This method will lead to an unbiased estimate of the treatment effect if pension status is exogenously determined so that the pensioners, Union 
veterans, were not selected in such a way that they received a larger or smaller pension income than the nonpensioners, Confederate veterans. ${ }^{4}$ It may appear at first that the exogeneity assumption is valid for this analysis because the pension status is determined by the eligibility requirements of the pension law, and the pensioners do not have to retire from work to be eligible. However, the endogeneity problems can still arise if the pension law was created to benefit Union veterans through eligibility restrictions on their characteristics, which differ substantially from those of the Confederates, and by creating pensionable conditions on these characteristics. In this case, the Union veterans would receive larger pension income than the Confederates would have received if they were granted pension. As a result, it is not possible to identify the treatment effect with a regression that includes as independent variables only individual characteristics that directly determine retirement because, even after controlling for these individual characteristics, the correlation between pension income and the unobserved elements brought about by selection problems is not trivial. In order to correct this problem, the regression must include variables that determine eligibility of pension status in order to control for the endogenous selection even if they are not related to the retirement decision.

Consequently, when using Confederate veterans as a control group for Union veterans who did not receive pensions, factors determining the eligibility requirement need to be quantified so that the treatment group and the control group can be compared by individual characteristics directly determining retirement as well as the eligibility characteristics that entitle the Union veterans to larger pension than a hypothetical Confederate eligible for the pension. Neither the disability pension system nor the service pension system considered occupation, wealth, or other factors that differentiated the North and the South as pensionable conditions. If the Confederates were admitted to the federal pension system, the amount of pension income they would have received would be approximately the same based on this consideration alone. However, since the federal pensions' financing depended to a large extent on the greater incentives and greater lobbying power for a generous pension of the Union veterans, the regression needs to account for the characteristics of the Union veterans that enhance their ability to finance the federal pension system.

The Union veterans were well organized and exerted substantial political influence through the Grand Army of the Republic (GAR). The GAR was responsible for the passage of several bills that extended pension benefits under the disability pension system, and strongly lobbied for the service pension system. According to Glasson (1918), the service pension system was financed by the maintenance of high import tariffs in the Northern

4. Using the nonveterans in the Northern states as a comparison group will create selection based on health because only healthy recruits were admitted into the army. 
economy. Since the Southern economy is very different from that of the North, it is unlikely that the Confederate veterans would be in a position to raise as much tariff revenue as the Union veterans - especially since there is far smaller industry in the South-or that they would be capable of lobbying to the same extent the GAR did. This suggests that the characteristics of the Northern economy, which can also be interpreted as a kind of eligibility requirement because they differentiate the North and the South, are correlated with the amount of pension income. As a result, state-level variables that summarize these economies need to be included in the regression of the veterans' labor force participation decisions.

Although various methods have been suggested, in the recent social program evaluation literature, for how to implement this regression and identify the treatment effect, the effectiveness of these estimators, when applied to historical data and the historical environments that generated them, is largely unknown. Most historical data available for statistical analysis lack sophisticated questionnaire designs, have small sample sizes, and contain limited numbers of variables. Application of many recently developed estimators will not always lead to better estimates of the treatment effect than the more traditional ones. The following analysis uses the matching method to control for the selection problem. The underlying assumption is that when the data are conditioned on economic characteristics of the Northern and Southern states, the problem will disappear, and the treatment effect can be recovered.

The analysis that follows is based on two sources of data. The first data set is cross-sectional data from the 1910 census obtained from IPUMS. It contains a 1 percent random sample of the 1910 census, which is the only census that asked whether the respondents were Civil War veterans and in which army the respondents served. The IPUMS data contain 617 Confederate veterans and 1,500 Union veterans. The second source of data is the life-cycle data of 4,528 Union veterans obtained from the CPE. This data set contains the variables from the 1910 census as well as the information from all of the veterans' federal pension applications, such as the amount of pension they received each year. ${ }^{5}$

Table 9.1 provides summary statistics for the two data sets. ${ }^{6}$ The participation rate of Union veterans is 55 percent. This is lower than the participation rate of the entire population in the same cohort, 66 percent, and the participation rate of Confederate veterans, 71 percent. The mean age is 69. Confederates had larger families and were more likely to live in farm households and rural areas. Their literacy rate was approximately 6 percent lower

5. The IPUMS data can be downloaded from www.ipums.umn.edu. The Union veterans data can be downloaded from www.cpe.uchicago.edu.

6. Since the IPUMS Confederate and Union samples are drawn from the same source, all variables can be compared. However, only some variables from the CPE Union sample can be compared with the IPUMS variables. 
Table 9.1

Summary Statistics for IPUMS Confederate, IPUMS Union, and CPE Union Samples

\begin{tabular}{|c|c|c|c|c|}
\hline \multirow[b]{2}{*}{ Variable } & \multicolumn{2}{|c|}{ IPUMS } & \multicolumn{2}{|c|}{ CPE Union } \\
\hline & Confederate & Union & 1910 & 1900 \\
\hline Number of observations & 617 & 1,500 & 4,528 & 7,023 \\
\hline Participation rate & $71 \%$ & $55 \%$ & $55 \%$ & $93 \%$ \\
\hline \multicolumn{5}{|l|}{ Age } \\
\hline Mean & 69.64 & 69.38 & 69.12 & 59.95 \\
\hline Standard deviation & 6.09 & 5.30 & 5.33 & 6.09 \\
\hline \multicolumn{5}{|l|}{ Family size } \\
\hline Mean & 4.13 & 3.03 & & \\
\hline Standard deviation & 2.42 & 1.85 & & \\
\hline \multicolumn{5}{|l|}{ Number of farm schedule } \\
\hline Mean & 1.64 & 1.27 & & \\
\hline Standard deviation & 0.55 & 0.47 & & \\
\hline Literacy rate & $88 \%$ & $94 \%$ & $94 \%$ & $95 \%$ \\
\hline Farm household & $61 \%$ & $27 \%$ & $24 \%$ & $40 \%$ \\
\hline Head of household & $79 \%$ & $77 \%$ & $84 \%$ & $93 \%$ \\
\hline Free of mortgage & $61 \%$ & $53 \%$ & $51 \%$ & $42 \%$ \\
\hline Own house & $70 \%$ & $68 \%$ & $64 \%$ & $64 \%$ \\
\hline Live in urban area & $14 \%$ & $36 \%$ & & \\
\hline Married & $73 \%$ & $71 \%$ & $75 \%$ & $86 \%$ \\
\hline
\end{tabular}

than that of Union veterans. The proportions of Confederate veterans who owned a house and of those who owned a house free of mortgage are higher than the corresponding proportions of Union veterans. Among the working veterans, more than 70 percent of Confederates were farmers, ${ }^{7}$ while less than 50 percent of Union veterans were.

The matching procedure could be implemented on the data without making functional form assumptions by forming cells and comparing the participation rate in each cell. Unfortunately, the data do not allow detailed conditioning without violating the condition that each cell must contain both pensioners and nonpensioners. Hence, it is desirable to pursue the matching exercise through regression analysis as well. Matching by cells clearly demonstrates the importance of conditioning. The difference in the participation rates between the Confederate and the Union veterans is substantially reduced when the data are conditioned by variables related to farming. These variables include a dummy indicating whether a veteran lived in an urban or a rural county, a dummy indicating whether a veteran

7. Occupational classification is based on the 1950 classification. In this paper, the classification is grouped into the 1950 category into four broad occupations: professionals, clerks, laborers, and farmers. Professionals include professional, technical, and managers and proprietors. Clerks include clerical and kindred workers, craftsmen, and service workers. Laborers consist of sales workers, operative workers, and laborers. Farmers include farmers and farm laborers. 
lived in a farm or nonfarm household, ${ }^{8}$ and the number of farm schedules ${ }^{9}$ (which indicates the number of farms the household operates). Table 9.2 shows that, when the veterans are compared by the number of farm schedules, the difference between the participation rates of Confederate and Union veterans is reduced substantially. When comparisons are made based on the urban county and farm household variables, the participation rate of the Confederate veterans lies between the participation rate of the IPUMS Union veterans and that of the CPE Union veterans. In addition, the participation rate of veterans who lived in farm households and rural counties are consistently higher than for those who lived in nonfarm households in all three samples.

The higher participation rates of the Confederate veterans in unconditional comparisons result from the fact that the labor force participation rate in the North is generally lower. ${ }^{10}$ This pattern, geographically plotted in figure 9.2, probably reflects the self-employment nature of the agricultural occupations in the South. ${ }^{11}$ This confirms that, in order to identify the treatment effect, it is necessary to compare (or match) participation rates of the Confederate and Union veterans by these characteristics because the pension law selected pensioners whose characteristics were systematically different from those of the general population in term of regional characteristics.

This can be implemented more effectively by imposing a functional form and estimating the regression equation. Denote the probability that each person participates in the labor force by $P_{1}$ if he is a pensioner, and $P_{0}$ if he is not. Let the value of $U$ be 1 if he is a Union veteran and 0 if he is a Confederate veteran. The treatment effect can be expressed as

$$
E\left(P_{1}-P_{0} \mid X, U=1\right)=F_{1}(X)-F_{0}(X)+E\left(v_{1}-v_{0} \mid X, U=1\right),
$$

where $F$ denotes a cumulative distribution function of labor force participation, which can be linear, logistic, or probit; $X$ stands for individual char-

8. According to IPUMS, a household is classified as farm household if it is located on a tract of three or more acres used for any agricultural operations, regardless of the amount of labor or produce involved. Alternatively, a household is considered a farm household if it is located on a tract of fewer than three acres that either yielded above $\$ 250$ in produce sales in the previous year, or employed at least one full-time farmer or agricultural laborer.

9. The number of farm schedules indicates how many farm schedules any member of the household received to be filled out for the agricultural census. It is a proxy for the number of farms the household member operated.

10. Most Union veterans were born in the northern states. Their pattern of residence had not changed much by 1910. The majority of Union veterans from both samples still lived in the East North Central (ENC), Middle Atlantic (MA), New England (NE), and Pacific (PC). The regional divisions are the same as census divisions.

11. Comparisons by head of household status, marital status, mortgage status, and home ownership status are also presented in table 9.1. The participation rate of the Confederate veterans is still significantly different from the participation rate of the Union veterans in both samples. The participation rate of Confederate veterans plotted by age and family size lies uniformly above that of Union veterans. 
Table 9.2

Participation Rate in 1910 by Head of Household Status, Marital Status, Mortgage Status, Home Ownership Status, Farm Household, and Number of Farm Schedules

\begin{tabular}{|c|c|c|c|c|c|}
\hline \multirow[b]{2}{*}{ Value } & \multirow{2}{*}{$\begin{array}{c}\text { IPUMS } \\
\text { Confederate } \\
\begin{array}{c}\text { Participation } \\
\text { Rate }(\%)\end{array}\end{array}$} & \multicolumn{2}{|c|}{ IPUMS Union } & \multicolumn{2}{|c|}{ CPE Union } \\
\hline & & $\begin{array}{l}\text { Participation } \\
\text { Rate }(\%)\end{array}$ & $x^{2}$ & $\begin{array}{c}\text { Participation } \\
\text { Rate }(\%)\end{array}$ & $\chi^{2}$ \\
\hline \multicolumn{6}{|c|}{ Head of household status } \\
\hline Head & 81 & 62 & $57.43^{*}$ & 63 & $64.13^{*}$ \\
\hline Nonhead & 33 & 28 & 0.87 & 28 & 1.51 \\
\hline \multicolumn{6}{|c|}{ Marital status } \\
\hline Married & 79 & 60 & $48.26^{*}$ & 62 & $49.39^{*}$ \\
\hline Widowed & 50 & 42 & 1.87 & 42 & $3.22 * * *$ \\
\hline \multicolumn{6}{|c|}{ Mortgage status } \\
\hline Mortgage & 76 & 67 & 2.07 & 74 & 0.128 \\
\hline Free & 76 & 56 & $41.47^{*}$ & 60 & 33.98 \\
\hline Missing & 60 & 46 & $9.51^{*}$ & 46 & $11.774^{*}$ \\
\hline \multicolumn{6}{|c|}{ Home ownership status } \\
\hline Own & 76 & 59 & $39.53^{*}$ & 63 & $29.31 *$ \\
\hline Rent & 64 & 61 & 0.38 & 67 & 0.35 \\
\hline Missing & 7 & 10 & 0.20 & 29 & $3.71 * * *$ \\
\hline \multicolumn{6}{|c|}{ Farm household status } \\
\hline Farm & 84 & 80 & 2.12 & 89 & $4.52 * *$ \\
\hline Nonfarm & 50 & 45 & 1.85 & 52 & 0.40 \\
\hline \multicolumn{6}{|c|}{ Number of farm schedules } \\
\hline 0 & 49 & 45 & 1.71 & & \\
\hline $1+$ & 85 & 83 & 0.75 & & \\
\hline \multicolumn{6}{|c|}{ Urban county status } \\
\hline Urban & 54 & 52 & 0.07 & 55 & 0.04 \\
\hline Rural & 73 & 56 & $45.61^{*}$ & 55 & $65.54 *$ \\
\hline
\end{tabular}

Notes: The Chi-squared statistic tests whether the participation rate of IPUMS Confederate is larger than the participation rate of the corresponding CPE veterans.

***Significant at the 10 percent level.

**Significant at the 5 percent level.

*Significant at the 1 percent level.

acteristics; $v$ is the unobserved elements; and the subscripts indicate the pensioners. By invoking the matching assumption, the treatment effect can be estimated in a regression with labor force participation as dependent variables. The estimation equation is $P=F_{0}(X)+U E\left(P_{1}-P_{0} \mid X, U=1\right)+\varepsilon$, and the treatment effect can be computed from $F_{1}(X)-F_{0}(X)$. In this analysis, the linear and logistic models will be estimated. It is important to note that the treatment effect need not be a constant in these models because it represents both the shift in the entire participation equation and the inter- 


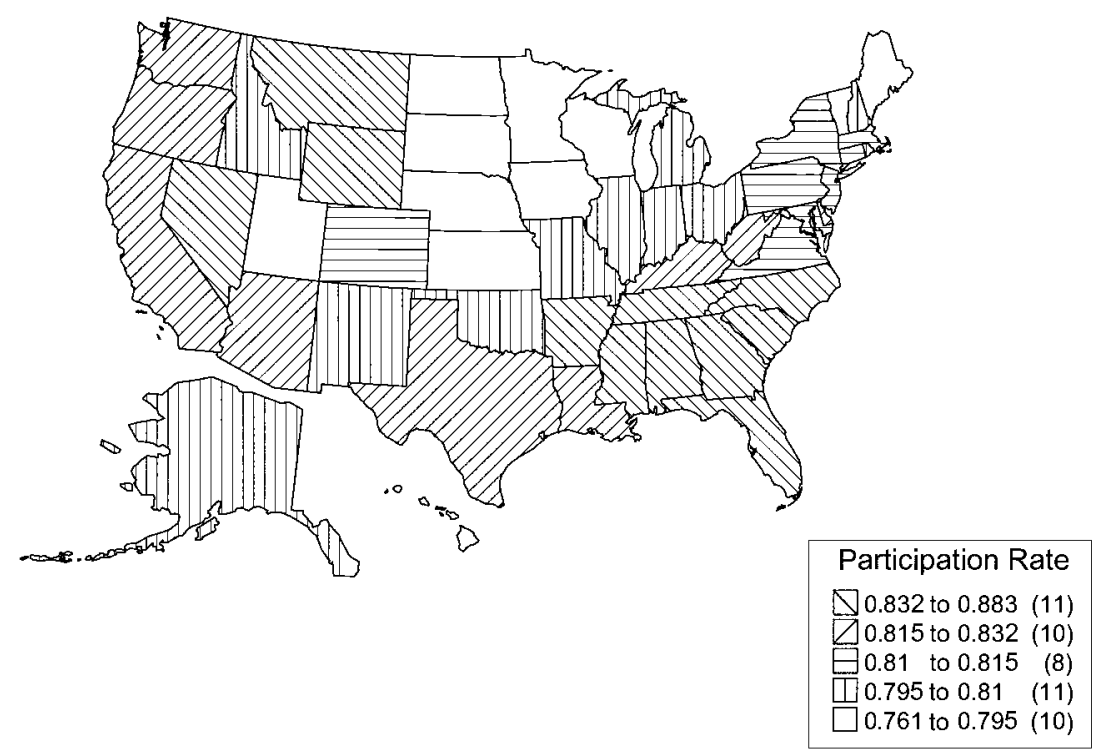

Fig. 9.2 Participation rate of male population over ten years of age in 1910 Source: U.S. Bureau of the Census (1912-14).

action of the shift with independent variables. To simplify the analysis it will be assumed that, with the exception of the intercept term, the coefficients of individual characteristics will be the same in both $F_{1}$ and $F_{0}$. With this assumption, the treatment effect in the linear model is the coefficient of the dummy variable indicating the Union veterans. For the logistic model, the treatment effect can be obtained by evaluating the difference between $F_{1}$ and $F_{0}$ at its own intercept, and the mean value of the explanatory variables.

The participation rate was regressed on the matching variables and some demographic variables that influence labor force participation decisions but do not affect selection, such as age, marital status, home ownership status, and head of household status. The matching variables were chosen to capture the differences in characteristics of the Union veterans, which are due mainly to regional differences. In the regression, these variables include a dummy variable indicating that the household received at least one farm schedule; a dummy for whether they lived in an urban county; a dummy for whether they were foreign-born; the state unemployment rate; the fraction of wage earners in their state; and the state's rank in manufacturing valueadded, total manufacturing value, number of industrial establishments, and number of industries. Data for state characteristics were obtained from the 1910 census of manufacturing.

Table 9.3 reports the estimation results for the entire sample. It is not surprising to find that participation declines with age, nor that veterans who 


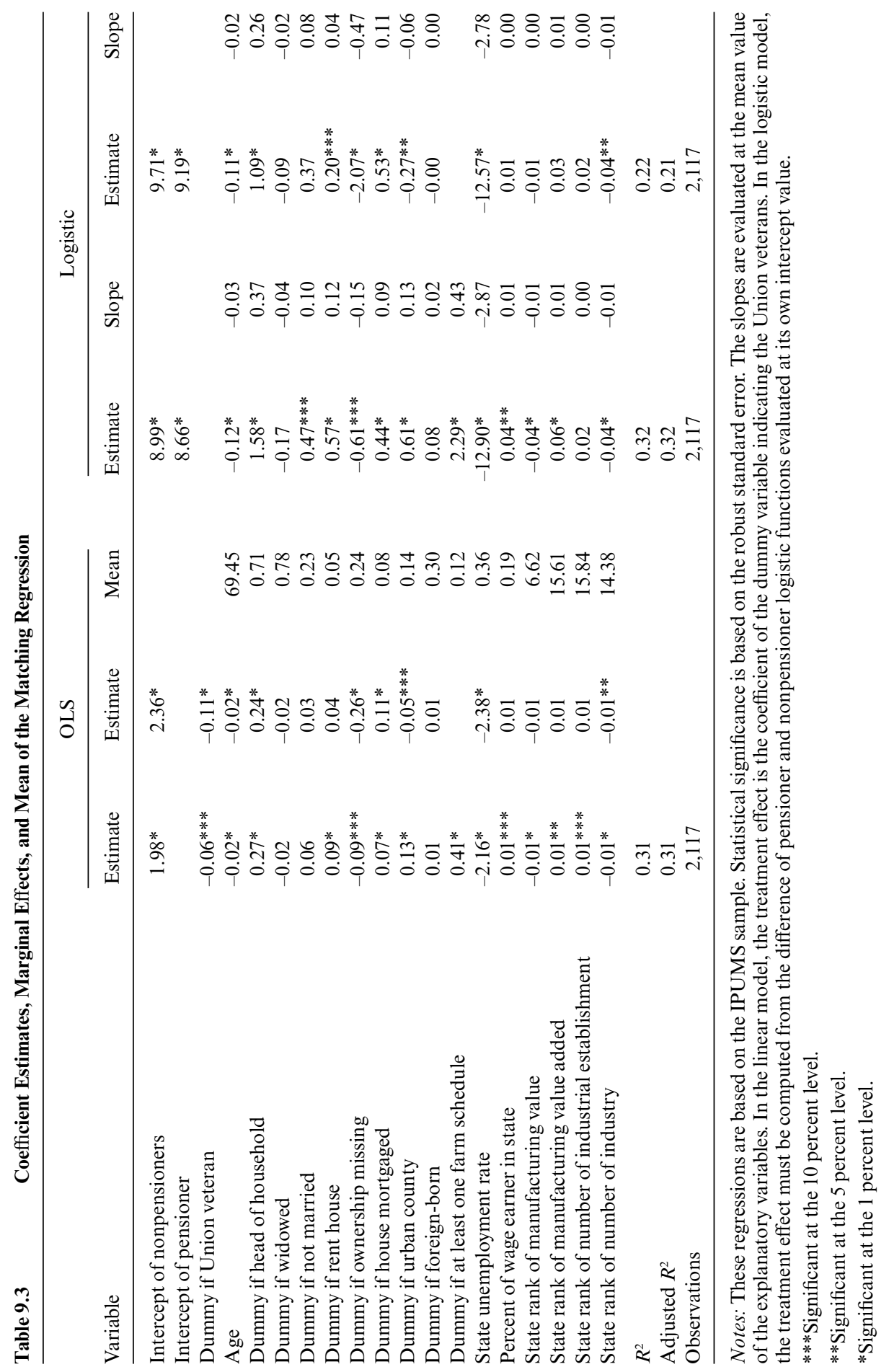


were heads of household and rented a house, or owned a home not free of mortgage, have higher participation rates. In both the linear and logistic models, the matching variables are statistically significant except the dummy for foreign-born. They suggest that the states that were more manufacturing intensive tended to consist of the veterans with lower participation rates. Veterans who lived in states with a high fraction of wage earners, a high manufacturing value-added, and a high number of industrial establishments were less likely to work. The number of farm schedules and the state unemployment rate also control for the higher participation rate in the South due to regional factors discussed earlier. The estimate of the treatment effect in the linear model can be read directly from the coefficient of the dummy variable indicating Union veteran status, which is 5.6 percent with the standard error of about 0.03 . For the logistic model, the estimate was computed by finding the difference of the probability of the participation of pensioners and nonpensioners evaluating the average value of the explanatory variables. This estimate is 8 percent.

The table also reports estimation results excluding the dummy variable for the number of farm schedules. The literature and the regression results based on Union veterans suggest that farmers who retire move away from their farms and do not operate any farms. The dummy variable for farm schedules might be picking up a retirement effect. Without the dummy variable, the treatment effect estimated from the linear model is 11 percent. The effect from the logistic model is 12 percent. It is interesting to note that the coefficient of the dummy for urban county became negative and significant. This probably reflects the effect of the farm schedule variable that was excluded.

When the sample was restricted only to the border states, the assumption that the veterans from both armies were similar is plausible. In this case, the border states restriction serves as a conditioning tool. The estimation results for the border states are reported in table 9.4. Age and head of household status remain significant predictors of participation rate. The estimate of the treatment effect is 6.2 percent from the linear model and 6.7 percent from the logistic model. The standard error is approximately 0.1 .

\subsection{Interaction Effects of Pension Income and Retirement}

A major issue in the previous section is the endogeneity of pension status. The Civil War pension eligibility requirements produced systematic differences in the characteristics of the pensioners. Estimations of the treatment effect account for these factors by comparing participation rates conditional on the regional characteristics. Another technique to estimate the effect of pension is to use the pension income to predict participation status among the pensioners. This method is usually implemented by estimating a discrete choice model on a sample, which is restricted to veterans who 
Table 9.4

Coefficient Estimates, Marginal Effects, and Mean of the Matching

Regression in the Border States

\begin{tabular}{|c|c|c|c|c|}
\hline \multirow[b]{2}{*}{ Variable } & \multirow[b]{2}{*}{ OLS Estimate } & \multicolumn{3}{|c|}{ Logistic } \\
\hline & & Estimate & Slope & Mean \\
\hline Intercept of nonpensioner & $1.82^{*}$ & 6.84 & & \\
\hline Intercept of pensioner & & $6.53^{*}$ & & \\
\hline Dummy if Union veteran & -0.06 & & & \\
\hline Age & $-0.02 *$ & $-0.10^{*}$ & -0.02 & 69.56 \\
\hline Dummy if head of household & $0.30^{*}$ & $1.35^{*}$ & 0.31 & 0.80 \\
\hline Dummy if widowed & -0.02 & -0.13 & -0.03 & 0.23 \\
\hline Dummy if not married & 0.16 & 0.87 & 0.15 & 0.04 \\
\hline Dummy if rent house & -0.01 & -0.11 & -0.02 & 0.25 \\
\hline Dummy if ownership missing & -0.12 & -0.69 & -0.16 & 0.05 \\
\hline Dummy if house mortgaged & 0.03 & 0.06 & 0.01 & 0.13 \\
\hline$R^{2}$ & 0.17 & & & \\
\hline Adjusted $R^{2}$ & 0.16 & & & \\
\hline Observations & 506 & & & \\
\hline
\end{tabular}

Notes: These regressions are based on the IPUMS sample. The slopes are evaluated at the mean value of the explanatory variables. In the linear model, the treatment effect is the coefficient of the dummy variable indicating the Union veterans. In the logistic model, the treatment effect must be computed from the difference of pensioner and nonpensioner logistic functions, evaluated at its own intercept value.

***Significant at the 10 percent level.

**Significant at the 5 percent level.

*Significant at the 1 percent level.

served in the Union Army and were eligible to receive a federal pension. This approach permits estimations of interaction effects, such as that between pension income and occupation. In addition, by including only pensioners in the regression, the estimation can use the more comprehensive data set available from the CPE. The pension effect is usually estimated by computing the change in the probability of participation between veterans who received larger amounts of pension and those with lower amounts. Denote the probability of being in the labor force by $P$ and the pension income by $I$; following the notations from the last section, the effect of pensions on labor force participation can be written as $[\partial E(P \mid X, U=1)] / \partial I$.

It is important to note that this parameter is different from the treatment effect. It reflects the interaction between pension status and pension income. The magnitude of the estimate measures the sensitivity of the probability of retirement of pensioners with respect to their pension income. Furthermore, this estimate applies only to the North. Since the CPE sample is a representative sample of the Northern white male population, estimation results based on the Union veterans alone will not suffer from selection problems. In the following discussion, the emphasis will not be on the selection issues that arise when comparing the Northern sample to the South- 
ern sample, but on the estimation results within the CPE Union sample. The aims are to compare the results with Costa's (1998a) analysis based on a smaller sample of the current CPE data, known as the twenty-company sample, and to estimate other interaction effects from the larger data set.

Economic theory provides a general framework that leads to using variation in pension income to estimate pension effects by assuming that the objective of veterans was to maximize their utility, subject to their lifetime budget constraints. They will choose to retire if their reservation wage is greater than the market wage. Pension income thus affects retirement decisions by changing the reservation wage. The reservation wage of veterans is represented by the marginal rate of substitution between consumption and labor supply. The decision to retire depends crucially on the determinants of the marginal rate of substitution, which is the amount of consumption after retirement. Denoting the market wage rate by $w_{t}$, the consumption by $c_{t}$, the labor supply by $l_{t}$, and the utility function by $U$, we can write the probability of observing a veteran working in period $t$ as

$$
\operatorname{prob}(\text { work at } t)=\operatorname{prob}\left[-\frac{U_{l_{t}}\left(c_{t}, 0\right)}{U_{c t}\left(c_{t}, 0\right)} \leq w_{t}\right] \cdot{ }^{12}
$$

Taking the first-order approximation of the marginal rate of substitution and market wage gives

$$
\begin{aligned}
-\frac{U_{l_{t}}\left(c_{t}, 0\right)}{U_{c_{t}}\left(c_{t}, 0\right)} & =X \beta+b C+\varepsilon, \\
w_{t} & =Z \varphi+\mu,
\end{aligned}
$$

where $C$ represents consumption, $X$ stands for socioeconomic variables that affect reservation wage, $Z$ stands for the proxy for wage, and $\varepsilon$ and $\mu$ are residuals. The probability of working at time $t$ is then

$$
\operatorname{prob}(\text { work at } t)=\operatorname{prob}(\varepsilon-\mu \leq Z \varphi-X \beta-b C) \text {. }
$$

Depending on the assumption about $\varepsilon$ and $\mu$, the above probability statement can be estimated by a linear, logistic, or probit regression with the observed retirement decision as the dependent variable and the variables $C, X$, and $Z$ as explanatory variables. The level of total consumption after retirement is determined by the veterans' full income after retirement, which depends upon total pension income and upon accumulated wealth. ${ }^{13}$ To proxy total income, several measures of pension income, home ownership status, and mortgage status are used. Proxies for reservation wage are age, health,

12. This expression can be obtained from the utility maximization problem. The optimality condition is the equality of the marginal rate of substitution and the ratio of price of consumption to wage rate, $\forall t,-\left(U_{l} / U_{c_{t}}\right) \geq w_{t}\left(>\right.$ if $\left.l_{t}=0\right)$.

13. In symbols, the consumption must satisfy $\sum_{t=R}^{T} c_{t} / 1+r_{t} \leq A_{0}+\sum_{t=R}^{T} A_{t} / 1+i_{t}$, where the summation is from the period in which the veterans retired to the period they died, and $A_{0}$ is the veterans' stock of wealth as of retirement. 
and various socioeconomic characteristics. Proxies for health include body mass index (BMI), wound rating, ${ }^{14}$ a dummy for whether the veteran was discharged from military service with a disability, the number of years the veteran lived after the census, and a dummy variable indicating whether the veteran served as a private. Body mass index was constructed by Song (2000). Both variables were created from the Surgeons' Certificates in the $\mathrm{CPE}$ data set. Other proxies for socioeconomic characteristics include marital status, a dummy for whether the veteran lived in a farm household, a dummy for whether the veteran was foreign-born, a dummy for whether the veteran lived in an urban county, ${ }^{15}$ and the state unemployment rate. The proxy for wage is occupation, which is divided into four broad categories: professional, clerk, laborer, and farmer. Retirees were assigned the most recent occupations stated in their pension applications before they retired.

Logistic regressions were estimated for cross-sectional samples from the 1900 CPE and the 1910 CPE Union veterans. The estimation results are reported in table 9.5. The estimates of the coefficients of annual pension income are negative and statistically significant. Using four alternative measures of pension income yields the same results. Table 9.6 reports the marginal effect, elasticity, and average change in participation rate due to the pension income. The probability of participation in 1910 is lower by 0.00076 for every dollar of average monthly pension income. If veterans were granted the average monthly pension, which is $\$ 188.70$, their participation rate would be lower by 14 percent $(=-0.00076 \cdot 188.70)$. Applying the same computation to other measures of pension income results in a reduction in participation rates between 6 and 14 percent. The estimated slope of the probability of retirement in 1910 from the twenty-company sample is 0.0112 , and the average annual pension income is $\$ 171.90$ (Costa, 1998a). If the veterans were given the average pension, their participation rate would be reduced by 19 percent $(=0.0112 \cdot 16.94)$, which is larger than the figures computed above. For 1900, the estimation implies a reduction in participation rates between 1 and 3 percent.

The estimated elasticity of retirement varies substantially with the measure of pension income used to calculate it. The elasticity computed from lifetime pension or nominal measure of pension tends to be larger than that computed from annual or real measures. ${ }^{16}$ In 1910, the maximum estimate (0.51) occurs when the monthly nominal pension income is used, and the

14. When veterans applied for pension, the federal Pension Board ordered them to take an examination conducted by a group of surgeons. The surgeons rated the veterans based on their overall health conditions as well as the specific conditions. The rating was then submitted to the Pension Board for approval (Glasson 1918). The wound ratings used in the regression are based on gunshot wounds or bodily injuries, most of which were due to the war. This variable is created by Mario Sanchez.

15. A county is defined as urban if it contains one or more cities with more than 25,000 inhabitants in 1910 .

16. Refer to figure 9.1 and note 3 for the discussion of nominal and real pension income. 


\begin{tabular}{|c|c|c|c|c|c|c|}
\hline \multirow[b]{2}{*}{ Variable } & \multicolumn{3}{|c|}{1910} & \multicolumn{3}{|c|}{1900} \\
\hline & Estimate & $\begin{array}{l}\text { Marginal } \\
\text { Effect }\end{array}$ & Mean & Estimate & $\begin{array}{c}\text { Marginal } \\
\text { Effect }\end{array}$ & Mean \\
\hline Intercept & $7.0011^{*}$ & & & $8.5126^{*}$ & & \\
\hline Monthly pension income & $-0.0049^{*}$ & -0.0008 & 188.6980 & $-0.0028^{* *}$ & -0.0002 & 166.5970 \\
\hline Dummy if professional & $1.9761^{*}$ & 0.3719 & 0.1050 & $1.9406^{*}$ & 0.0384 & 0.1440 \\
\hline Dummy if clerk & $2.0876^{*}$ & 0.4148 & 0.2040 & $1.5655^{*}$ & 0.0366 & 0.2010 \\
\hline Dummy if laborer & $1.3795^{*}$ & 0.3045 & 0.2290 & $1.6471^{*}$ & 0.0397 & 0.2300 \\
\hline Interaction professional & $0.0029 * *$ & 0.0004 & 20.1860 & 0.0018 & 0.0001 & 25.0850 \\
\hline Interaction clerk & 0.0005 & 0.0001 & 38.1940 & $0.0008 * *$ & 0.0000 & 32.8600 \\
\hline Interaction laborer & $0.0025^{*}$ & 0.0004 & 42.8460 & 0.0004 & 0.0000 & 37.3320 \\
\hline Age & $-0.0889 *$ & -0.0138 & 69.1160 & $-0.0525^{*}$ & -0.0028 & 59.9460 \\
\hline $\begin{array}{l}\text { Dummy if head of } \\
\text { household }\end{array}$ & $1.4477^{*}$ & 0.3436 & 0.8170 & $0.5707 * *$ & 0.0240 & 0.9190 \\
\hline Dummy if not married & -0.1950 & -0.0484 & 0.0570 & 0.2940 & 0.0087 & 0.0500 \\
\hline Dummy if widowed & $-0.1894^{*}$ & -0.0469 & 0.1900 & $-0.3653^{*}$ & -0.0141 & 0.0920 \\
\hline Dummy if rent house & $0.4485^{*}$ & 0.1073 & 0.1610 & $0.1920^{*}$ & 0.0062 & 0.2600 \\
\hline $\begin{array}{l}\text { Dummy if ownership } \\
\text { missing }\end{array}$ & -0.7244 & -0.1791 & 0.2000 & $0.4167 * *$ & 0.0120 & 0.1030 \\
\hline $\begin{array}{l}\text { Dummy if house } \\
\text { mortgaged }\end{array}$ & $0.4058^{*}$ & 0.0971 & 0.1210 & $0.3746^{*}$ & 0.0113 & 0.1980 \\
\hline $\begin{array}{l}\text { Dummy if nonfarm } \\
\text { household }\end{array}$ & $-3.4545^{*}$ & -0.6757 & 0.5730 & $-3.4656^{*}$ & -0.1421 & 0.5460 \\
\hline $\begin{array}{l}\text { Dummy if nonfarm } \\
\text { missing }\end{array}$ & $-2.0043 *$ & -0.4510 & 0.1920 & $-2.9067^{*}$ & -0.3075 & 0.0920 \\
\hline Dummy if urban county & 0.0992 & 0.0244 & 0.3140 & $-0.2621^{*}$ & -0.0093 & 0.2650 \\
\hline State unemployment rate & -0.1721 & -0.0267 & 0.2010 & $-5.9103 * *$ & -0.3150 & 0.2100 \\
\hline Dummy if foreign-born & -0.0896 & -0.0221 & 0.1400 & -0.1140 & -0.0040 & 0.1490 \\
\hline $\begin{array}{l}\text { Number of years lived } \\
\text { after census }\end{array}$ & $0.0631^{*}$ & 0.0098 & 9.6170 & $0.0257 * * *$ & 0.0014 & 15.5150 \\
\hline $\begin{array}{l}\text { Dummy if BMI not } \\
\text { missing }\end{array}$ & $-2.8620 * * *$ & -0.4947 & 0.8230 & $-3.8484^{*}$ & -0.0622 & 0.8330 \\
\hline BMI & $0.2108 * * *$ & 0.0327 & 19.0220 & $0.2958^{*}$ & 0.0158 & 19.2640 \\
\hline $\mathrm{BMI}^{2}$ & $-0.0040^{* * *}$ & -0.0006 & 450.1540 & $-0.0058^{*}$ & -0.0003 & 455.5460 \\
\hline $\begin{array}{l}\text { Dummy if discharged } \\
\text { with disability }\end{array}$ & -0.0623 & -0.0154 & 0.1880 & $-0.4072 * *$ & -0.0153 & 0.1940 \\
\hline $\begin{array}{l}\text { Dummy if wound rating } \\
\text { not missing }\end{array}$ & 0.0202 & 0.0050 & 0.1230 & 0.2013 & 0.0063 & 0.1360 \\
\hline Wound rating & -0.0587 & -0.0091 & 0.2050 & -0.1345 & -0.0072 & 0.2210 \\
\hline Dummy if not private & 0.1324 & 0.0323 & 0.0940 & 0.1444 & 0.0046 & 0.1070 \\
\hline$R^{2}$ & 0.3436 & & & 0.0871 & & \\
\hline Rescaled $R^{2}$ & 0.4634 & & & 0.2265 & & \\
\hline Observations & 4,540 & & & 7,007 & & \\
\hline
\end{tabular}

Notes: These regressions are based on the CPE sample. Statistical significance is based on the robust standard error. The slope reported here was computed by averaging the individual slope calculated from the predicted probability of each observation.

***Significant at the 10 percent level.

**Significant at the 5 percent level.

*Significant at the 1 percent level. 
Table 9.6

Mean, Marginal Effect, and the Mean Pension Effect

\begin{tabular}{lccc}
\hline Pension Income & Mean & Marginal Effect & Mean Pension Effect \\
\hline \multicolumn{2}{c}{1910 Census } & \\
Average monthly pension & 188.70 & $-7.61 \mathrm{E}-04$ & -0.1436 \\
Average monthly real pension & 223.85 & $-5.23 \mathrm{E}-04$ & -0.1171 \\
Total pension & $6,474.65$ & $-1.97 \mathrm{E}-05$ & -0.1274 \\
Total real pension & $8,122.86$ & $-9.29 \mathrm{E}-06$ & -0.0754 \\
Annual pension in 1910 & 190.21 & $-2.94 \mathrm{E}-04$ & -0.0559 \\
Total pension 1900-10 & $1,630.38$ & $-3.81 \mathrm{E}-05$ & -0.0622 \\
Total real pension 1900-10 & $1,962.90$ & $-3.14 \mathrm{E}-05$ & -0.0616 \\
& 1900 Census & \\
Average monthly pension & 166.60 & $-1.51 \mathrm{E}-04$ & -0.0251 \\
Average monthly real pension & 149.75 & $-1.16 \mathrm{E}-04$ & -0.0174 \\
Total pension & $5,291.87$ & $-3.78 \mathrm{E}-06$ & -0.0200 \\
Total real pension & $4,928.50$ & $-2.26 \mathrm{E}-06$ & -0.0111 \\
Annual pension in 1900 & 119.27 & $-1.31 \mathrm{E}-04$ & -0.0157 \\
Total pension 1890-1900 & $1,133.59$ & $-1.39 \mathrm{E}-05$ & -0.0157 \\
Total real pension 1890-1900 & $1,382.77$ & $-1.12 \mathrm{E}-05$ & -0.0155 \\
\hline
\end{tabular}

Notes: This table is based on the CPE sample. The level of significance is computed relative to farmers' elasticity.

***Significant at the 10 percent level.

**Significant at the 5 percent level.

*Significant at the 1 percent level.

minimum estimate $(0.18)$ occurs when the annual pension received in 1910 is used. The maximum elasticity from the 1900 sample (0.43) occurs when the monthly average pension is used, while the minimum ( 0.19$)$ occurs when the lifetime real pension is used. Each estimate reflects a different behavioral aspect. The estimate of lifetime pension income reflects responses that include expectation of pension income in the future, while the estimate using pension income from 1900 or 1910 does not. Consequently, the estimates using lifetime or average measures tend to be larger. This result suggests that veterans reacted more toward the annuity feature of the federal pension than toward the amount of pension in a particular period. In addition, the lower estimates from real measures of pension income suggest that, to a large extent, the veterans simply considered the nominal monetary value of the pension income when making retirement decision.

Comparisons of the elasticity between 1910 and 1900 do not provide a clear trend as to whether elasticity is rising or falling. Elasticities computed from lifetime pension are rising from 1900 to 1910, while those computed from pension income received around 1910 and 1900 are falling. Nevertheless, all computed elasticities are significantly larger than zero, which confirms the hypothesis that, in contrast to findings from recent studies on social security, the income elasticity of retirement fell after 1910. The 1910 estimate from the twenty-company sample, 0.47 , is very close to the current 
Elasticity of Retirement with Respect to Pension Income by Occupation

\begin{tabular}{lccccc}
\hline & Noninteracted & Farmer & Professionals & Laborers & Clerks \\
\hline \multirow{2}{c}{ 1910 Census } & & & \\
Average monthly pension & $-0.5123^{*}$ & -0.4382 & $-0.2928^{* * *}$ & $-0.2515^{* *}$ & -0.5121 \\
Average monthly real pension & $-0.3894^{*}$ & -0.3381 & -0.7183 & -0.3912 & -0.2891 \\
Total pension & $-0.4544^{*}$ & -0.4016 & -0.5206 & $-0.2705^{* *}$ & $-0.3640^{* * *}$ \\
Total real pension & $-0.2468^{*}$ & -0.2186 & -0.3591 & -0.1778 & $-0.0935^{* *}$ \\
Annual pension in 1910 & $-0.1826^{* *}$ & -0.1622 & -0.5197 & $-0.5139^{*}$ & -0.0795 \\
Total pension 1900-10 & $-0.2001^{*}$ & -0.1810 & -0.4324 & $-0.3777^{* *}$ & -0.2266 \\
Total real pension 1900-10 & $-0.1982^{*}$ & -0.1794 & -0.4202 & $-0.3644^{* *}$ & -0.2221 \\
& & 1900 Census & & & \\
Average monthly pension & $-0.4395^{*}$ & -0.4389 & -0.1721 & -0.3716 & -0.3153 \\
Average monthly real pension & $-0.3014^{*}$ & -0.3033 & -0.2380 & -0.3923 & -0.2057 \\
Total pension & $-0.3509^{*}$ & -0.3671 & -0.5220 & -0.3172 & -0.2852 \\
Total real pension & $-0.1925^{*}$ & -0.2001 & -0.2395 & -0.2121 & -0.0962 \\
Annual pension in 1900 & $-0.2699^{*}$ & -0.2809 & -0.2887 & -0.1086 & -0.2217 \\
Total pension 1890-1900 & $-0.2707^{*}$ & -0.2856 & -0.2702 & -0.2205 & -0.1744 \\
Total real pension 1890-1900 & $-0.2661^{*}$ & -0.2811 & -0.2645 & -0.2304 & -0.1680 \\
\hline
\end{tabular}

Notes: This table provides the elasticity from the regression based on the CPE sample. The level of significance is computed relative to farmers' elasticity.

***Significant at the 10 percent level.

**Significant at the 5 percent level.

*Significant at the 1 percent level.

estimate for the monthly nominal pension income, 0.51 , and the lifetime nominal pension income, 0.45 . However, the current 1900 estimate is lower than the estimate based on the twenty-company sample, $0.73 .{ }^{17}$

Table 9.7 shows that several of the pension-occupation interactions are statistically significant, although the magnitudes of the interaction effect vary with the measure of pension income used in the regression. In 1910, the majority of the estimates indicate that professionals are the most sensitive to pension income, followed by clerks. Farmers and laborers are the least sensitive. Professionals are also the most sensitive to pension in 1900 , followed by laborers and clerks. The most radical difference is that the income elasticity of farmers had become almost as sensitive as that of professionals by 1900. Furthermore, the occupation dummies together with the farm dummy variables indicate that farmers who lived in farm households are the most likely to participate in the labor market, and farmers who live in nonfarm households are the least likely. The majority of the latter type of farmers were retired. This result confirms the findings in Costa (1995a) and Lee (1999), who found that liquidating farms was a strategy for financing retirement.

17. The difference might be related to the sample size. Costa's 1910 estimate is based on the twenty-company sample combined with a sample of veterans from Ohio, while her 1900 estimate is based on the twenty-company sample alone. 
Most farmers exited the labor force either by transferring their farms to their children or by selling to outsiders. Ostergen (1981) found that the latter method was gaining popularity when land values increased between 1885 and 1915. High participation rates among farmers and the reduction in retirement elasticity from 1900 to 1910 may have resulted both from the increase in land values and from the self-employed nature of the occupation.

The regressions also suggest a considerable health effect. In both regressions, the number of years the veterans lived after the census and both the linear and quadratic BMI are statistically significant. The longer the veterans lived after the census, the less likely they were to retire. The estimated coefficients of BMI suggest that participation rates initially rose as BMI increased, but that after BMI reached 26.35 in 1910 and 25.59 in 1900, participation rates fell. Costa (1998a) also found an inverted U-shaped relationship between the retirement rate and BMI in the twenty-company sample. Furthermore, veterans who were discharged from military service with disabilities were less likely to participate in the labor market. This effect is statistically significant in the 1900 sample. The estimate for wound rating, which measures the severity of body wounds (mainly due to gunshots) during the war, is negative, as expected, but not significant. The veterans who served as nonprivates were more likely to participate in the labor force.

There is no conclusive evidence that different cohorts behaved differently. In general, participation rates decline with age, but the interaction term between pension income and age is not statistically significant. The 1910 regressions generate positive estimates, while the 1900 regressions generate negative estimates. Similarly, the interaction term between pension income and urban/rural status is not significant, although urban/rural status by itself is significant. In 1900, the estimate is negative, suggesting that veterans living in urban areas are more likely to retire. The estimate is positive but not significant in 1910. This result is consistent with the estimation based on the twenty-company sample, which produced the same pattern.

Other findings are as follows. A veteran who was head of household, rented a house, or had mortgage on an owned house was more likely to participate in the labor market. There is no evidence that foreign-born veterans behaved differently. Both widowed and single veterans were more likely to retire. Veterans who had missing values in the own/rent variables and farm household status were significantly less likely to participate. The estimates also suggest that veterans who rented their homes had a higher probability of labor force participation. Homeowners were likely to be more wealthy, allowing them to stay outside the labor market.

\subsection{Concluding Remarks}

This paper has examined the effect of the federal pension system on the labor force participation of Civil War veterans. The paper has made two 
major points. First of all, pension laws created systematic differences in characteristics of pensioners and nonpensioners through eligibility requirements. A substantial portion of the difference between the participation rates of Confederate and Union veterans is due to these differences. The identification of the treatment effect needs to account for this selection problem. The findings based on the matching methods suggest a strong impact of pensions on labor force participation. Second, variations in pension income among the Union veterans explain the differences in their participation rates by as much as 15 percent. The estimated effect depends on the measure of pension income used in the regression. The elasticity of retirement with respect to pension income also varies between occupations.

It is hoped that this study will encourage further research into long-term retirement patterns in America. By looking at the historical data, this research demonstrated the importance of military pension and farm liquidation as means to finance retirement. Although Social Security replaced these methods and became widely used, the continuous decline in labor force participation reflects a stable and persistent process that underlies the economics of retirement and remains to be examined further.

\section{References}

Costa, Dora L. 1993. Health, income, and retirement: Evidence from nineteenthcentury America. Ph.D. diss. University of Chicago.

1995a. Agricultural decline and the secular rise in male retirement rates. Explorations in Economic History 32 (4): 540-52.

1995b. Pensions and retirement: Evidence from Union army veterans. Quarterly Journal of Economics 110 (2): 297-320.

1998a. The evolution of retirement: An American economic history. Chicago: University of Chicago Press.

1998b. The evolution of retirement: Summary of a research project. American Economic Review 88 (2): 232-36.

Fogel, R. W. 1998a. Public use tape on the aging of veterans of the Union army: Military, pension, and medical records. Version M-4. Chicago: University of Chicago, Graduate School of Business, Center for Population Economics.

-1998b. Public use tape on the aging of veterans of the Union Army: U.S. federal census records. Version C-2. Chicago: University of Chicago, Graduate School of Business, Center for Population Economics.

Glasson, William H. 1918. Federal military pensions in the United States. New York: Oxford University Press.

Heckman, James. 1997. Instrumental variables: A study of implicit behavioral assumptions in one widely used estimator. Journal of Human Resources 32 (3): 44161.

Heckman, James, H. Ichimura, and P. Todd. 1997. Matching as an econometric evaluation estimator: Evidence from evaluating a job training program. Review of Economic Studies 64 (4): 605-54. 
1998. Matching as an econometric evaluation estimator. Review of Economic Studies 65 (2): 261-94.

Lee, C. 1998. The rise of the welfare state and labor-force participation of older males: Evidence from the pre-social security era. American Economic Review 88 (2): $222-26$.

1999. Farm value and retirement of farm owners in early-twentieth-century America. Explorations in Economic History 36 (4): 387-408.

- 2000. Labor market status of older males in early twentieth century America. University of Chicago. Working paper. Available at [http://www.cpe. uchicago.edu].

Ostergen, Robert. 1981. Land and family in rural immigrant communities. Annals of the Association of American Geographers 71 (3): 400-11.

Preston, Samuel, and Michael Haines. 1991. Fatal years: Child mortality in latenineteenth-century America. Princeton, N.J.: Princeton University Press.

Ruggles, Steven, et al. 1997. Integrated public use microdata series. Version 2.0. Minneapolis: University of Minnesota Historical Census Projects.

Song, Chen. 2000. Cleaning of the height and weight variables in the Union Army Military and Surgeons' Certificates data sets. University of Chicago. Working paper. Available at [http://www.cpe.uchicago.edu].

U.S. Bureau of the Census. 1912-14. Thirteenth census of the United States taken in the year 1910. Washington, D.C.: GPO.

-1975. Historical statistics of the United States, colonial times to 1970. Washington, D.C.: U.S. Bureau of the Census. 